\section{Germplasm Release of Four High-artemisinin Clones of Artemisia annua L.}

\author{
Hazel Y. Wetzstein and Jules Janick \\ Department of Horticulture and Landscape Architecture, Purdue University, \\ West Lafayette, IN 47907-2010
}

\section{Jorge F.S. Ferreira}

U.S. Salinity Laboratory, United States Department of Agriculture, Agricultural Research Service, Riverside CA 92507

Additional index words. annual wormwood, malaria, qinghao, sweet Annie
Artemisia annua L., a native of China, is now widely naturalized and cultivated as an antimalarial medicinal plant. It is known under the name of qinghao in China and annual wormwood or sweet Annie in the United States. The tall shrubby annual plant blooms under short days and produces tiny flowers and seeds. Glandular trichomes, abundant in leaves and inflorescences, are the source of the nonvolatile sesquiterpene arteannuin A, best known as artemisinin or qinghaosu, effective against drug-resistant Plasmodium falciparum, responsible for the often-fatal cerebral malaria. Artemisinin combination therapies (ACTs) are presently the first-line treatment for malaria in the tropics. Yields of artemisinin from seedgrown plants average $0.7 \%$ in Africa and Asia. Artemisia has not been commercially cultivated as a medicinal crop in the United States, but trials have been performed in Washington state to determine its use as an alternative coccidiostat to replace organic arsenic use in poultry. Furthermore, trials are currently underway in Kentucky in an attempt to produce raw material for ACTs in fields previously used to grow tobacco.

Four clones of artemisia with artemisinin concentrations varying from $1.81 \%$ to $2.16 \%$ have been identified based on research carried out at Purdue University and at the be the source of improved germplasm, and clonal propagation through tissue culture or cuttings (already used in African plantations) could be practical methods for field production of homogeneously high-artemisinin clones.

Artemisia annua seed obtained from China and Brazil and their open pollinated progeny were grown in a greenhouse and field at Purdue to research artemisinin (Ferreira, 1994; Ferreira and Janick, 1994, 1996; Ferreira et al., 1995). In 2007, plants and seed from this material were sent to the

Received for publication 11 July 2019. Accepted for publication 28 Aug. 2019.

J.J. is the corresponding author. E-mail: janick@ purdue.edu. University of Georgia. This material could
University of Georgia for studies of floral anatomy, micropropagation, and selection (Wetzstein et al., 2014, 2018). Selections were made over successive generations at the University of Georgia from 2007 to 2014, based on agronomic characteristics such as leaf area, shoot biomass, flowering time, and artemisinin concentration. Selections were cloned by cuttings and maintained in a greenhouse under long days. Cloned material was used in field evaluation trials.

\section{Description}

The performance of our target selections was evaluated in field plots that were located at the University of Georgia campus in Athens, GA, and at the University of Georgia Horticulture Farm in Watkinsville, GA. Studies were conducted using a randomized complete block design in 2012, where seven genotypes were compared using four replications (rep or reps), with each containing eight plants per rep (i.e., 32 plants per genotype). In 2013, a large-scale field plot study was conducted to evaluate six genotypes containing eight reps with eight plants per rep (i.e., 64 plants per genotype). Additional guard-row plants were used along the perimeter of plots. Spacing was at one plant per square meter. No supplemental irrigation or fertilization was provided, nor were herbicides or pesticide applied. Plots were hand weeded as needed.
Plants were harvested before flowering (27 Aug. 2013) because that was previously determined to be the peak in artemisinin concentration for plants of both Brazilian and Chinese origin (Ferreira et al., 2018). Characteristics including height, width, stem dry weight, and leaf dry weight were assessed. Leaf samples were oven-dried at $50{ }^{\circ} \mathrm{C}$, and artemisinin analysis was conducted following a validated protocol described by Ferreira and Gonzalez (2009).

The performance and leaf morphology of six clonal selections are presented in Table 1 and Fig. 1. Genotypes exhibited outstanding levels of artemisinin, which ranged from $1.8 \%$ to $2.16 \%$ artemisinin on a dry weight basis, and high shoot biomass. Leaf dry weight ranged from 2.46 to $3.88 \mathrm{t}$ per hectare based on the one plant per square meter spacing used in field studies. Higher-density planting practiced by some growers could possibly increase both leaf and artemisinin yield per hectare. Data regarding artemisinin concentration and biomass have been used to predict potential artemisinin content per hectare. Clone $\mathrm{C} 1$ plants, with an average artemisinin content of $2.16 \%$, had triple the average concentration obtained in seed-propagated material and a calculated yield of $70.7 \mathrm{~kg} / \mathrm{ha}$ at one plant per square meter. The best four genotypes produced $>55 \mathrm{~kg} / \mathrm{ha}$ of artemisinin per acre.

\section{Availability}

Four clones, C1, C10, B6, P137, are freely released by the Agriculture Experiment Stations of Purdue University and the University of Georgia. Cuttings can be obtained by contacting Jules Janick (janick@purdue.edu). A FedEx account number must be provided.

\section{Literature Cited}

Ferreira, J.F.A. 1994. Production and detection of artemisinin in Artemisia annиа. L. Ph.D. thesis. Purdue University, West Lafayette, IN.

Ferreira, J.F.S. and J.M. Gonzales. 2009. Analysis of underivatized artemisinin and related sesquiterpene lactones by high-performance liquid chromatography with ultraviolet detection. Phytochem. Anal. 20:91-97.

Ferreira, J.F.S. and J. Janick. 1994. Production and detection of artemisinin in Artemisia аппиа
Table 1. Artemisinin concentration per plant and $\mathrm{kg} / \mathrm{ha}$ from six selected clones of Artemisia annua.

\begin{tabular}{|c|c|c|c|c|c|c|c|c|c|}
\hline \multirow[b]{2}{*}{ Genotype } & \multicolumn{3}{|c|}{ Artemisinin (\%) } & \multirow{2}{*}{$\begin{array}{l}\text { Plant ht } \\
(\mathrm{cm})^{\mathrm{z}}\end{array}$} & \multirow{2}{*}{$\begin{array}{l}\text { Plant width } \\
(\mathrm{cm})^{\mathrm{z}}\end{array}$} & \multirow{2}{*}{$\begin{array}{l}\text { Stem dry } \\
\text { wt }(\mathrm{kg})^{\mathrm{z}}\end{array}$} & \multicolumn{2}{|c|}{ Leaf dry $w^{z}$} & \multirow{2}{*}{$\begin{array}{l}\text { Artemisinin } \\
(\mathrm{kg} / \mathrm{ha})^{\mathrm{z}}\end{array}$} \\
\hline & $\overline{2012}$ & 2013 & Avg & & & & $(\mathrm{kg})$ & $\overline{(t / h a)}$ & \\
\hline$\overline{\mathrm{C} 1}$ & 2.13 & 2.19 & $2.16 \mathrm{a}$ & $179 \mathrm{a}^{\mathrm{y}}$ & $113 \mathrm{a}$ & $0.69 \mathrm{a}$ & $0.32 \mathrm{ab}$ & 3.22 & 70.6 \\
\hline $\mathrm{C} 10$ & 1.93 & 2.13 & $2.03 \mathrm{ab}$ & $188 \mathrm{a}$ & $106 \mathrm{ab}$ & $0.77 \mathrm{a}$ & $0.28 \mathrm{ab}$ & 2.81 & 59.9 \\
\hline B6 & 1.65 & 2.21 & $1.93 \mathrm{ab}$ & $181 \mathrm{a}$ & $112 \mathrm{ab}$ & $0.67 \mathrm{a}$ & $0.26 \mathrm{ab}$ & 2.61 & 57.8 \\
\hline P137 & 1.93 & 1.68 & $1.81 \mathrm{bc}$ & $192 \mathrm{a}$ & $111 \mathrm{ab}$ & $0.81 \mathrm{a}$ & $0.39 \mathrm{a}$ & 3.88 & 65.2 \\
\hline P63 & 1.81 & 1.53 & $1.67 \mathrm{c}$ & $144 \mathrm{~b}$ & $100 \mathrm{bc}$ & $0.44 \mathrm{~b}$ & $0.25 \mathrm{~b}$ & 2.46 & 37.7 \\
\hline B4 & 1.83 & 1.37 & $1.60 \mathrm{c}$ & $140 \mathrm{~b}$ & $89 \mathrm{c}$ & $0.34 \mathrm{~b}$ & $0.27 \mathrm{ab}$ & 2.65 & 36.3 \\
\hline
\end{tabular}

$\mathrm{z}_{2012 \text { data. }}$

${ }^{\mathrm{y}}$ Mean separation Tukey test, $\alpha=0.05$.

Artemisinin productivity is based on leaf dry weight, $1 \mathrm{plant} / \mathrm{m}^{2}$, and without considering a commercial extraction loss of $25 \%$. Means within the same column followed by the same letter are not significantly different. 


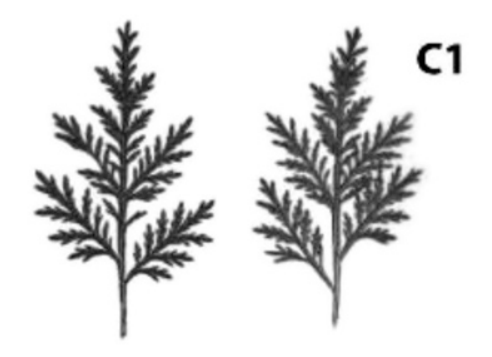

P137
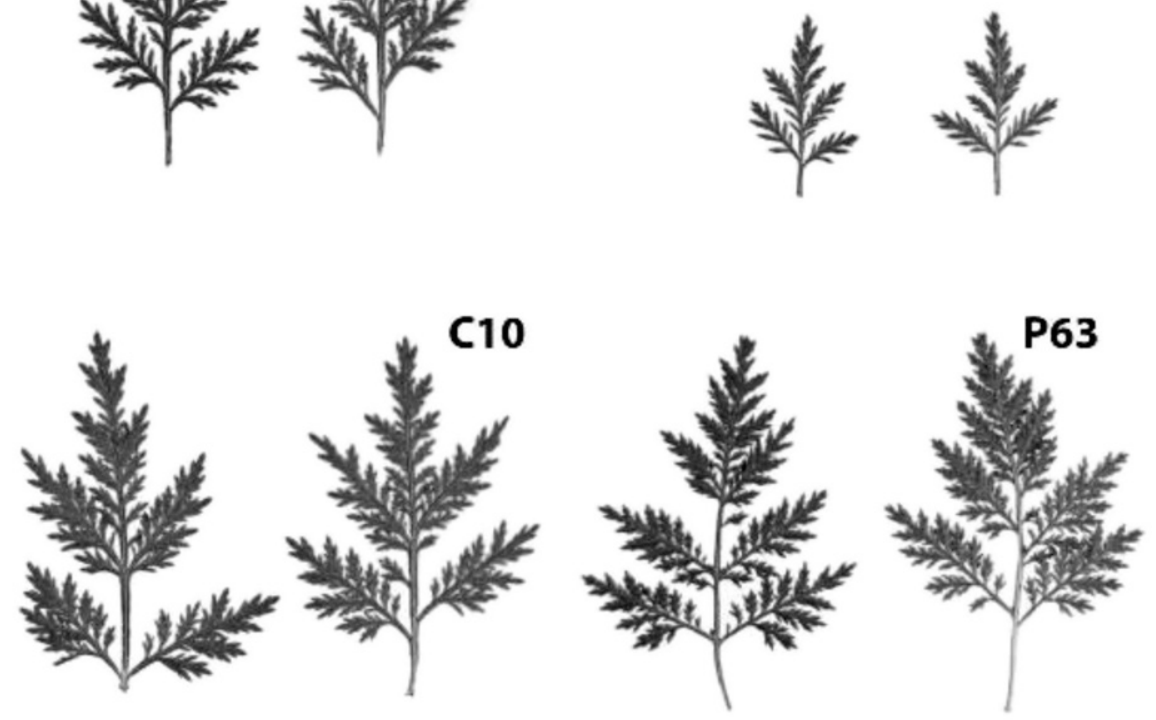

B6
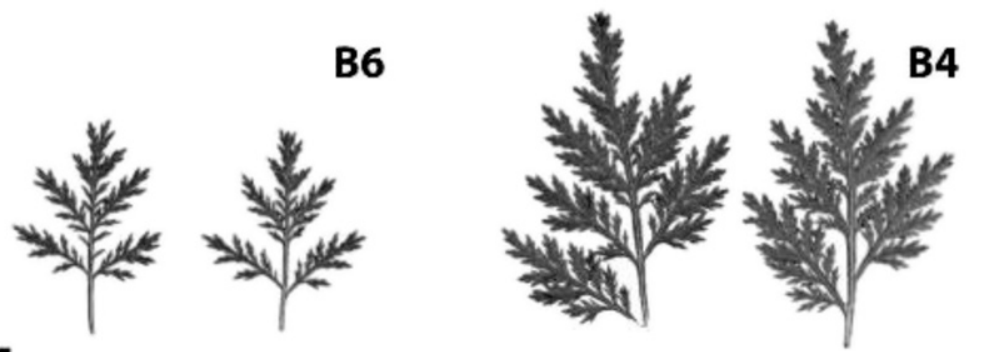

Fig. 1. Variation in the leaf size of six selected clones of Artemisia апnиа grown under field conditions $($ bar $=2 \mathrm{~cm})$. with special reference to trichomes. Intl. J. Plant Sci. 156:807-815.

Ferreira, J.F., J.E. Simon, and J. Janick. 1995. Artemisia annua: Botany, horticulture, pharmacology. Hort. Rev. 19:310-371.

Ferreira, J.F.S. and J. Janick. 1996. Immunoquantitative analysis of artemisinin from Artemisia аппиа using polyclonal antibodies. Phytochemistry 41:97-104.

Ferreira, J.F.S., V.A. Benedito, D. Sandhu, J.A. Marchese, and S. Liu. 2018. Seasonal and differential sesquiterpene accumulation in $\mathrm{Ar}$ temisia annua suggest selection based on both artemisinin and dihydroartemisinic acid may increase artemisinin in planta. Front. Plant Sci. 9:1096, doi: 10.3389/fpls.2018.01096.

Wetzstein, H.Y., J.A. Porter, J. Janick, and J.F.S. Ferreira. 2014. Flower morphology and floral sequence in Artemisia аппиа (Asteraceae). Amer. J. Bot. 101:875-885, doi: 10.3743/ ajb.1300329.

Wetzstein, H.Y., J.A. Porter, J. Janick, J.F.S. Ferreira, and T.M. Mutui. 2018. Selection and clonal propagation of high artemisinin genotypes of Artemisia annua. Front. Plant Sci. 9:358, doi: 10.3389/fpls.2018.00358. 